\title{
RÉGIÓK ÉS REGIONALIZÁCIÓ
}

\section{(Regions and Regionalisation)}

\section{ILLÉS IVÁN}

Kulcsszavak:

régió, regionalizáció, regionális politika, decentralizáció

A szerzö tanulmányában a régiók kialakulását, a regionalizáció folyamatát elemzi az Európai Unióban és Magyarországon. Bemutatja a decentralizációs törekvések összefüggését a demokratikus döntési mechanizmussal.

A magyar sajtóban egyre gyakrabban szerepel a régiók és a regionalizálás kérdése. Új intézményeket (pl. Regionális Fejlesztési Tanácsokat) hoztunk létre, amelyek összetétele politikai vitakérdéssé vált. Az EU csatlakozás követelményeinek egyik fontos eleme a régiók szintjén tervezési, fejlesztési, finanszírozó és ellenörző intézmények és szakmai kapacitások kiépítése. E kérdésekben természetesen különbözö érdekcsoportok eltérő nézeteket képviselnek és ennek hangot is adnak. Egyszóval a régiók és a regionalizálás kérdése mára egyértelműen „be van dobva” a köztudatba. E tanulmány megírásának kettős célja volt:

Az egyik cél egyfajta ,illúzió- illetve tévhit-oszlatás”. A tapasztalatok szerint mind Nyugat-Európában a közép-kelet-európai régiók, regionalizmus helyzetéről, mind a közép-európaiaknak a nyugati országok régióiról egyoldalú és ezért irreális képük van. A nyugatiak a kelet-európai országokat, mint abszolút központosított államokat képzelték el, ahol a demokrácia hiánya egyben totális centralizációt is jelentett. Keleten viszont a nyugati regionalizmusról, decentralizációról vannak idealizált elképzelések. Rejlik ezen idealizálás mögött némi propagandista szándék is, mintegy követendő példákat - és egyben elvárásokat - állítva a közép-európai intézményépítés elé. De tisztázást igényel néha saját intézményeink valós jellege, funkciója is, mert a politikától átitatott közélet és sajtó azokról gyakran csak ellentétesen végletes torzképeket fest.

A másik cél vita kiváltása. Bár a tanulmány nem kifejezetten vitacikk, de felveti azokat a kérdéseket, amelyek további eszmecserét igényelnek. A tanulmány szerzöje a regionalizmus híve, de nem akármilyen regionalizmusé. A tanulmányban - talán éppen ezért - a regionalizálással, különösen a gyors, radikális regionalizálással szembeni ellenérvek dominálnak. Ưgy véljük ugyanis, hogy ezeket az ellenérveket mi, regionális kutatók ismerjük legjobban, és ezért a mi kötelességünk, javaslataink kialakítása elött, azokat megválaszolni. 


\section{Regionalizáció és az Európai Unió}

Az Európai Unió és a régiók, a regionalizáció kapcsolatában két, bár egymással összefüggő, de mégis egészen más jellegú témát kell megvizsgálnunk:

- A régiók befolyása és szerepe az Európai Unió teljes döntéshozatali rendszerében;

- A régiók mint az Európai Unió kohéziós és strukturális politikájának alanyai.

1) Az Európai Unió nemzetállamok szövetkezéséből jött létre és mindmáig az is maradt. Döntéshozatali mechanizmusának alapvető hordozói a nemzetállamok kormányai, amelyek döntéseiket konszenzussal hozzák. Mindazonáltal, az Európai Unió egyben politikai szervezet is, amely meghatározott politikai értékeket valló országok szövetkezéseként jött létre, és e politikai értékek között elökelö helyet kap a demokrácia, a polgárok akaratának demokratikus eszközökkel való érvényesítése az országok és az Unió politikájában is. E demokratikus akaratérvényesítés konkrét módjáról azonban a tagországok eltérỏ nézeteket vallanak.

Több ország a demokratikus berendezkedés fontos feltételének tekinti a decentralizációt, a helyi önkormányzatok, a régiók hatáskörének erösítését. Ezekben az országokban a régiók jelentős kompetenciákkal rendelkeznek, a nemzeti kormányok döntéseire jelentôs befolyást gyakorolhatnak. A régiók számára az európai integráció fejlódésének bizonyos tendenciái aggodalmat keltőek és sérelmesek voltak. Egyrészt az Európai Bizottság az idők folyamán a nemzeti szintról magához vont olyan hatásköröket és kompetenciákat, amelyek az adott országokban nem is a nemzeti kormányok, hanem a regionális kormányzatok hatáskörébe tartoztak. Másrészt, miközben e régiók, tartományok a nemzeti döntéshozatalra jelentős befolyással voltak, gyakorlatilag semmiféle intézményes beleszólási joguk nem volt az Európai Unió, az Európai Bizottság döntéshozatali rendszerébe, a bizottság kizárólag a nemzeti kormányokkal tartott kapcsolatot.

A nyolcvanas évek végén, a kilencvenes évek elején mozgalom indult hát a „háromszintes Európa”, a „régiók Európája” megteremtésének, a középső, regionális szint hatásköre növelésének, de fooleg az európai integrációs folyamatokba való nagyobb beleszólásának érdekében. A mozgalom fö erejét természetesen a föderatív államok (akkor Németország és Belgium, azóta Ausztria is) törvényhozói hatáskörökkel és széles körü jogokkal rendelkező nagy régiói, legelső sorban a német tartományok képviselték, méghozzá a német szövetségi kormány eröteljes támogatásával. A német támogatás nélkül valószínủleg sohasem érték volna el azokat az eredményeket, amelyeket elértek. A mozgalom sikereinek csúcsát 1993-ban a maastrichti szerződés aláírása jelentette. A szerződés három olyan lényeges új elemet tartalmazott, amelyek a regionalizmus, a regionális szint EU-n belüli egyértelmú térnyerését jelentették. 
Ezek a következők:

- a szubszidiaritás elvének a szerződésben való explicit megjelenése;

- a Régiók Bizottságának, mint az Európai Tanács és az Európai Bizottság mellett múködő tanácsadó, véleményezö szervezetnek a létrehozása;

- annak lehetővé tétele, hogy az Európai Tanácsban, az Európai Unió legfőbb döntéshozó szervében egyes üléseken a szövetségi államokat ne azok központi kormányai, hanem a tartományok képviselhessék.

Maastricht óta azonban a mozgalom dinamikája nagymértékben alábbhagyott, egyes esetekben még visszalépés is bekövetkezett. Ez részben annak tudható be, hogy az Európai Unió érdeklődése az utolsó hét évben más kérdésekre koncentrálódott (a közös pénz megteremtése, a közös kül- és biztonsági politika, a keleti bővítés, a balkáni válság stb.). A visszalépésben, a hanyatlásban azonban jelentös szerepe volt annak is, hogy a központi kormányok nem akarták, a régiók pedig nem tudták kihasználni azokat a lehetőségeket, amelyeket a maastrichti szerződés biztosított:

A szubszidiaritás magasztos elvének gyakorlati megvalósitási módja mindvégig homályos maradt. A maastrichti szerzödés nem mondta ki világosan, hogy az csak az Európai Bizottság és a nemzeti kormányok, vagy a nemzeti kormányok és a régiók viszonylatában is érvényesítendö-e? Számos olyan kormány volt (például Margaret Thatcheré), amely azt kizárólag Brüsszel és a nemzeti kormány közötti viszonylatra értelmezte.

A Régiók Bizottsága 1993-ban alakult meg. A nevével ellentétben azonban mégsem a régiók bizottsága lett. A francia-német (Mitterand - Kohl) kompromisszum eredményeként ugyanis abban helyet kaptak nemcsak a régiók, hanem a helyi önkormányzatok, városok és községek képviselöi is. Ez utóbbiak már az eredeti bizottságban is többségben voltak a régiók képviselöivel szemben (96:93), és arányuk a későbbi években csak növekedett. A települések és a régiók érdekei számos esetben egybeeshetnek, más esetekben eltérhetnek, vagy akár szembe is kerülhetnek egymással. A bizottság összetetele azonban lehetetlenné tette a sajátos régió-szintủ érdekek képviseletét, és paradox módon éppen a Régiók Bizottsága szavazott gyakran a régiók megerôsitése ellen. De valószínüleg egységesebb képviselet sem változtatott volna érdemben a helyzeten. A Régiók Bizottsága eleve csak véleményezö szerepkörrel jött létre, a döntéshozó Európai Bizottság és annak szervei azonban még e szerepkört sem mindig méltányolta. Előfordult, hogy a Régiók Bizottsága fontos dokumentumokat még véleményezésre sem kapott meg, ha pedig megkapta és véleményezte, a döntéshozatalnál e véleményeket nem igazán vették figyelembe. A helyzet, e tekintetben, az utóbbi időben javulni látszik.

Paradox módon azonban a Régiók Bizottságának elismertségét éppen egy másik maastrichti vívmány vetette vissza leginkább, mégpedig az, hogy a föderatív államok régiói részt vehetnek a szövetségi kormányok képviseletében az EU legfontosabb döntéshozó testületének, az Európai Tanácsnak, a kormányfök 
testületének ülésein. Ausztria, Belgium és Németország tartományait illeti meg ez a jog. Ez azt jelenti, hogy ezeknek az erős régióknak, a regionális mozgalom korábbi vezető erőinek, érdekeik érvényesítése érdekében nincs többé szükségük a Régiók Bizottságára, hiszen érdekeiket közvetlenebbül, az Európai Tanács ülésein is érvényesíthetik. De, ha a szövetségi kormány éppen nem is ruházza át a képviseletet, e tartományoknak országukban is megvan az alkotmányos lehetőségük (a német tartományoknak pl. a Bundesratban, a Szövetségi Tanácsban), hogy érdekeiket érvényesitsék. Megszủnt tehát számukra a Régiók Bizottságának fontossága és ennek megfelelően is kezelik azt. A Régiók Bizottsága tehát „elveszítette" legfontosabb tagjait, a többi régió politikai súlya messze elmarad a szövetségi államok tartományaitól, talán még a spanyol és olasz régiók képviselnek jelentős súlyt.

Talán még lehangolóbb képet kapunk, ha azt vizsgáljuk meg, mire használták fel ezek a szövetségi tartományok megnövekedett befolyásukat az Európai Unióban. Semmiképpen sem a „régiók Európájának”, azaz általában a regionális szintnek az erösítésére, hanem sajátos, a többiektől megkülönböztetett érdekeik érvényesítésére. Egyrészt arra, hogy a „törvényhozási hatáskörökkel rendelkező”, tehát a föderatív országokban levő tartományok valamint néhány spanyol tartomány, a többiekhez képest többlet jogokat kapjanak, pl. hogy csak nekik legyen joguk jogorvoslatért az Európai Bírósághoz fordulni, másrészt arra, hogy az Európai Unió versenyszabályozásában bizonyos területeken kivételes elbánást élvezhessenek, pl. a saját rádió-és televízióadók, vagy a saját bankok, takarékpénztárak esetében. Még, ha ez irányú kezdeményezéseiket nem koronázta is minden esetben siker, a célok és törekvések iránya meglehetősen egyértelmü.

2) A regionalizáció és a régiók az Európai Unió strukturális politikájában 1988 óta jutottak különleges szerephez. Az Európai Uniónak természetesen voltak strukturális politikára, regionális fejlesztésre szánt pénzeszközei 1988-at megelőzően is. Ezeket az összegeket azonban országkvóták szerint osztották fel, a kvơták szerint kapott összegeket a nemzeti kormányok kezelték. A kormányok a regionålis fejlesztési pénzeszközöket egyes projektek finanszírozására használták fel. A támogatások ágazati és regionális elosztása a kormányok hatáskörében történt, az Európai Bizottságnak ezen arányokról még áttekintése is alig volt, befolyása még kevésbé. Ez a gyakorlat az Európai Bizottságot más megoldás keresésére késztette. Az új megoldás a strukturális alapok regionalizációja volt. $\mathrm{Az}$ Európai Bizottság ugyan már a hetvenes évek végén, nyolcvanas évek elején felkérte a tagországok statisztikai hivatalait, hogy a területi adatokat egységes és lehetöleg összehasonlítható területi egységekre, az ún. NUTS egységekre (Nomenclature des unités statistiques territoriales) állítsák össze és közöljék. Így kapóra jött, hogy a statisztika NUTS rendszere már készen állt, ezek az eredetileg kizárólag statisztikai célokra kialakított területi egységek váltak a fejlesztési 
politika alanyaivá: az ún. NUTS 2, nagyobb egységek az elmaradottság felszámolását célzó, a NUTS 3, kisebb egységek a szerkezeti váltást célzó támogatásoké. Ezáltal természetesen a regionalizálás jellege, szerepköre és szempontjai is lényegesen megváltoztak. Ezután a fejlesztési, támogatási eszközöket nem országokra, hanem arra jogosult régiókra osztották fel, a jogosultsági kritériumokat pedig a Bizottság állapította meg. A váltást természetesen a régiók megnövekedett jelentöségével indokolták meg, és ez részben meg is felel a valóságnak. Nem lehet nem észrevenni azonban, hogy e változtatás közvetve az Európai Bizottságnak a nemzeti kormányokkal szembeni pozíciója megerősitését is célozta, kritériumaival most már a Bizottság határozta meg, mintegy a nemzeti kormányokon ,átnyúlva”, a strukturális alapok egyes országokon belüli felhasználási helyét és arányait.

Az Európai Bizottság így, a strukturális alapok felosztásának reformja révén a regionalizáció élharcosává vált, noha szándékai eleinte minden bizonnyal szerényebbek voltak. Az új szerepkör azonban nem minden országban találkozott teljes egyetértéssel ${ }^{1}$, és a célok megvalósítása is felemás volt. Ha eltekintünk Luxemburgtól és Írországtól, ahol az egész országterület egyetlen régió, akkor az Európai Unió fennmaradó 13 tagállamából hétben, tehát több mint felében a struktúrapolitika szempontjából jelentős NUTS 2 egységek mindmáig nem képeznek közigazgatási egységet (hanem kisebb egységeknek a csoportosításából jöttek létre), és nincs is szándék számukra közigazgatási jogállás teremtésére. De a NUTS 2 egységekkel egybeeső önkormányzati régiók a másik hat országban sem az EU strukturális politika és támogatás ösztönzésére, hatására jöttek létre, hanem már korábban is léteztek. Való igaz, hogy a „regionalizált” támogatásokat nem lehet a kedvezményezett régiókon kívül felhasználni, de ahol az egész ország, vagy annak nagy része támogatott, ott bizony a kormányok elég szabad kezet kapnak a támogatás régiók közötti elosztásában, vagy újraelosztásában, és nem mindig a leginkább rászoruló régiók javára (Portugáliában, Görögországban, de részben Írországban is e támogatások igen jelentős hányada a föváros és környéke fejlesztését szolgálta). A strukturális alapok „regionalizálását” tehát fenntartásokkal kell kezelni. A tapasztalat azt mutatja, hogy az alapok nagyobb részét olyan nagy horderejú országos projektekre, beruházásokra fordítják, amelyekről a központi kormányok döntenek (miközben azok fizikailag természetesen a kedvezményezett régiókban valósulnak meg), a regionális szintü döntési hatáskörben legfeljebb a strukturális alapok 15-25 százaléka kerül elosztásra, illetve megvalósításra. A tervek, programok előkészitése, egyeztetése oly hosszú ideig kizárólag az Európai Bizottság és a nemzeti kormányok bürokráciája között folyik, hogy a régiókkal való egyeztetésre, érdemi együttmüködésre már nem jut idő, azok igy nem vehetnek részt lényeges döntési folyamatokban. 
A regionalizálás a strukturális politika menedzselése szempontjából természetesen indokolt. Az Európai Unió tagállamainak közvetlenül a központi kormányzat alatti szinten összesen 335 adminisztratív területi egysége van, ráadásul e területi egységek országonként igen különbözö nagyságúak. Az Európai Bizottság adminisztratív kapacitásait meghaladta volna 335 különböző területi egységre bontott és részletezett strukturális célok kidolgozása, finanszírozása, figyelemmel kísérése és ellenörzése. Az egységesítés és regionalizálás az ún. NUTS 2 szint egységeinek számát 208-ra redukálta, ami még mindig igen nagy szám, de már jobban kezelhető. Az Európai Bizottság a jelenlegi tagországokkal szemben nem lépett fel sohasem a területi közigazgatás megváltoztatásának igényével - ez egyértelmủen nemzeti szintü és nem uniós hatáskör - hanem „csak” azzal a kívánalommal, hogy ezen egységek szintjén a tervezés, programozás, finanszírozás és ellenőrzés szakmai és lebonyolítási intézményei álljanak rendelkezésre. Ezek technikai és nem közigazgatási, még kevésbé politikai feltételek.

Tény azonban, hogy a decentralizációnak és a regionalizációnak az Európai Bizottság - ha nem is expressis verbis, de „ráutaló magatartással” más jelentőséget tulajdonít az EU keleti bővítése során, az újonnan csatlakozni kívánó országokkal szemben. Amit az Európai Bizottság bár preferál, de nem erőltet a jelenlegi tagállamok esetében, annak különös nyomatékot ad az új csatlakozó országokban. Része van ebben persze annak is, ami kívülállók és bekerülni kívánók között más tárgyalási témákban szintén megfigyelhető, hogy az újakkal szemben olyan követelményeket állítanak, amelyeket a már birtokon belül lévőkkel szemben már nem tudnak érvényesíteni. Van azonban e hozzáállásnak egy másik és fontosabb eleme is. Az új csatlakozó országok demokratikus rendjét az Unió képviselői még nem érzik teljesen stabilnak és megszilárdultnak, és széles körủ az a meggyőződés, hogy a decentralizáció, a hatáskörök alacsonyabb szintekre helyezése fontos garanciája, mi több mozgatóereje a demokratikus rend megszilárdításának. A strukturális politika valójában egyben olyan eszköz is, amelyen keresztül a decentralizációt, mint kívánatos politikai célt kívánják elérni. Ezért elengedhetetlen, hogy a következő alfejezetben ezt a kérdést, a decentralizáció, regionalizáció és a demokrácia összefüggés-rendszerét tüzetesebben megvizsgáljuk.

\section{Regionalizáció és demokrácia}

Számos nyugat-európai országban, de föleg Németországban általános az a nézet, hogy a decentralizáció - és ezen belül a regionalizáció - a demokratizálásnak fontos előfeltétele és egyben velejárója. A decentralizáció egyrészt a döntések lakossághoz közelebbi szinthez való levitelét, a nagyobb részvétel lehetöségét jelenti. Másrészt az alsó és középső szintek hatáskörének megerősítése egyben hatalmi ellensúlyt képez az állami központi kormányzattal szemben, és ezáltal egyfajta garanciát 
jelent az állami túlhatalommal szemben. Nem véletlen, hogy a második világháború után a totális diktatúrákat Németországban, Ausztriában és Olaszországban föderalizált, vagy regionalizált államokként szervezték újjá, és az sem, hogy Spanyolországban a Franco-rendszer után kezdődött el a jelentősebb arányú decentralizáció és regionalizáció.

Mindez igaz. Mégis megfeledkeznek több fontos momentumról azok, akik a középés délkelet-európai országokban ma a decentralizációt és regionalizációt sürgetik:

Az első, hogy a regionalizáció és föderalizáció elfogadtatása Nyugat-Európában is több évtizedet vett igénybe. Az Allensbach Közvéleménykutató Intézet rendszeresen feltette a kérdést a nyugatnémet lakosságnak, nem volna-e egyszerübb a tartományi kormányokat, parlamenteket egyszerủen feloszlatni és egy egységes német államot létrehozni. 1952-ben a német lakosság 54 százaléka nagyon jónak, jónak vagy elfogadhatónak tekintette ezt a javaslatot, 1960-ban 31, 1974-ben 26, 1980-ban pedig már csak 17 százalék (Kinsky 1995). A szövetségi tartományok 1947. évi létrehozásától 33 év volt szükséges a népesség nagy többségének a föderalizáció helyességéröl való meggyözéséhez. Olaszországban már az 1947. évi alkotmány tartalmazta a regionalizáció szükségességét, de annak megvalósítására csak a hetvenes-nyolcvanas években került sor;

Különösen nehéz ez a meggyözés a közép- és kelet-európai volt szocialista országokban, ahol a központi tervgazdálkodás évtizedeiben a régiók (megyék, vajdaságok, oblasztyok stb.) egy igen sajátos funkciót töltöttek be. Bár gazdálkodásuk és döntéseik általános, politikai keretei és ágazati arányai felülröl szigorúan meg voltak szabva, lefelé, a városok és községek felé viszonylag nagyfokú elosztási és újraelosztási szabadsággal rendelkeztek, és ezzel a szabadsággal nagymértékben éltek és vissza is éltek több évtizeden át. A települések, városok és községek ezekkel az önkényes döntésekkel, ezzel a kiszolgáltatottsággal asszociálták, asszociálják a regionális közigazgatást, és ez volt az oka annak, hogy szinte minden országban a rendszerváltás liberális törvényhozói első ténykedéseinek egyike volt a régiók megfosztása újraelosztási, pénzosztogató hatalmuktól és hatáskörüktöl;

Van egy mélyebb történelmi emlékezet is. Kelet- és Délkelet-Európa lakói, akik történelmük nagy részében abszolutisztikus, sőt gyakran despotikus birodalmak keretében éltek, a regionalizációval és széttagoltsággal egyáltalán nem a több demokráciát, hanem ellenkezőleg, a nagyobb elnyomást és önkényt asszociálják. Az Oszmán Birodalomban egyértelmüen a legrosszabb idők azok voltak, amikor a szultán nem volt képes a pasákat és agákat ellenörizni, és azok kíméletlen elnyomást valósítottak meg saját hatalmi területükön. Hasonló az orosz történelem tanulsága is. A Habsburg Birodalomban némileg más volt a helyzet, de azért itt is számos nemzetiség - a románok, szerbek, horvátok, szlovákok, ukránok - a központi hatalomhoz, az uralkodóhoz füzték reményeiket a helyi - megyei vagy 
keruileti - magyar és lengyel hatalommal szemben. A szlovén nép mindmáig annak a történelmi traumának a hatása alatt él, hogy etnikumuk a monarchiában hat különböző régió, koronatartomány között volt megosztva, és ezért mindenfajta regionalizációval ellenségesen állnak szembe;

Vannak továbbá egészen friss tapasztalatok is, mindenekelőtt Oroszországban. $\mathrm{Az}$ orosz régiók önállósodási törekvései a kilencvenes évek elején semmiképpen sem sorolhatók a demokratizálás elemei közé. Éppen ellenkezőleg: ez az önállósodási törekvés az előző rendszerben megszerzett pozíciók megtartását, a régiók erőforrásainak egy szük regionális oligarchia általi kisajátitását szolgálta elsősorban. Ezzel szemben a központosítás, bár hatalmi, pénzügyi aspirációktól ugyancsak nem mentesen és korántsem mindig jogállami eszközökkel, de mégiscsak pozitívabb szerepet játszott. Ennek az oligarchikus „regionalizmusnak” elöször Jelcin 1993-ban parancsolt megálljt a „Fehér ház ostromakor”, majd Putyin 2000-ben a parlament felső házának reformjával tovább korlátozta azt (amennyiben megszüntette a regionális kormányzók felsőházi tagságát). Bár a régi kiskirályok új populista jelszavak jegyében való regionális uralma elsősorban a FÁK-országokra jellemzó, korántsem korlátozódik csak e térségre (gondoljunk csak Gheorghe Funár kolozsvári regnálására). Továbbá a regionalizmusnak aggodalomra okot adó kinövései a fejlett demokráciákban is tapasztalhatók. Elég egy pillantást vetni arra, hová jutott el az észak-olasz és a flamand regionalizmus, ahol az azt korábban képviselö pártok egyes vezetöi ma már rasszizmusba és idegengyứlöletbe hajló jelszavak jegyében politizálnak. Általában megfigyelhetö, hogy populista és radikális irányzatok szövetségi illetve regionalizált államokban elöször regionális szinten tudnak képviseletre, hatalomra szert tenni és e bázisról kísérlik meg befolyásukat tovább növelni. Ilyen összefüggésben említhető Jörg Haider karinthiai regnálása, vagy Le Pen dél-franciaországi bázisa is;

Ugyancsak megfigyelhetó - nyugaton és keleten egyaránt -, hogy amikor szubszidiaritásról, a hatáskörök alsóbb szintek számára való átengedéséről van szó, a politikusok hajlamosak arra saját kompetenciájuk növelése érdekében hivatkozni, de kevesebb buzgalommal folytatják e decentralizációt a saját szintjüktól „lefelé”. Pl. Bajorországnak, amely leghatározottabban kủzd a szövetségi kormány hatalmának korlátozásáért, olyan alkotmánya van, amely a legcentralizálóbb jellegü a német tartományok között, és a helyi önkormányzatoknak a legkorlátozottabb autonómiát tesz lehetővé.

A regionalizáció igen gyakran a demokratizálás kardinális kérdéséből a napi politika ügyévé degradálódik, és ez Európa mindkét felében megfigyelhetö. Franciaországban pl. a gaullista párt kifejezetten ellenezte a regionalizációt, míg ellenzékük, a szocialisták a regionalizáció és decentralizáció hívének vallották magukat. 1981-ben, amikor a szocialisták hatalomra kerültek, meg is tették az első fontos lépéseket a regionális reform érdekében. Alig több, mint egy évvel később, 
1983-ban azonban a helyhatósági választásokon a régiók többségében a polgári ellenzék került hatalomra és ettől kezdve a szocialisták lelkesedése a regionalizáció, a regionális autonómia iránt nagymértékben lecsökkent. De nem haladt az ügy jelentősen előre később a polgári tábor parlamenti győzelme után sem, mert - bár az ő pozíciójuk a régiókban erős volt - a polgári politikusok jelentős része az egész regionalizációt a szocialisták művének tekintette, ami eleve az ördögtől való. Lengyelországban az 1989. és 1990. évi szabad választások után a vajdaságok jelentős hányadában a szocialista, volt állampárt tartotta meg pozícióit, ezért a Szolidaritás bázisán alakult központi kormány közigazgatási reformot akart végrehajtani, nagyobb régiókat akart szervezni, hogy az ellenzék vajdasági hatalmi bázisát megszüntesse. Ideje azonban e reform végrehajtására már nem volt, az új választásokon hatalomra került szocialisták pedig az egész közigazgatási reformot ad acta tették. Az 1997-ben újra hatalomra került Szolidaritás ismét elövette, de most az elöző időszak tanulságai alapján azt gyorsan akarta végrehajtani. A gyors végrehajtás, a nem megfelelő előkészités miatt azonban olyan problémák keletkeztek, amelyek máig jelentös feszültségeket okoznak. A csehországi reformfolyamat abban különbözik, hogy ott 1990-ben a régiókat megszüntették, azok tehát nem képezhették a bázisát egyetlen pártnak sem. A Klaus-kormány kifejezetten centralizáló és régióellenes volt, ennek megfelelően ellenzékének, a szociáldemokratáknak régió-pártinak kellett lennie. E régió-pártiságot tovább erösítette, hogy 1990-ben regionális autonomista, morva és sziléziai pártalakulatok viszonylag jelentös számú szavazót tudtak megnyerni maguknak, és a szociáldemokraták a decentralizáció jelszavának átvételével kívánták e szavazótábor kegyeit elnyerni. Hatalomra jutásuk után neki is láttak a regionális reformnak. Nem számoltak azonban annak nehézségeivel, így a régiók alkotmányos müködésének megkezdése az eredeti határidöhöz képest máris legalább egy évet késik. De más gondok is vannak: 14 - magyar megye nagyságú - régiót hoztak létre, amelyek az EU struktúrapolitika igényeit nyilvánvalóan nem elégítik ki. Felvetỏdik a kérdés: ha már egyszer átfogó területi átszervezést hajtanak végre, akkor miért nem igazodnak jobban ezekhez a követelményekhez. Azonban nem tettek eleget a morva és sziléziai autonomista szavazók elvárásainak sem, hiszen az új régiók nem tartják tiszteletben Morvaország és Szilézia több száz éves hagyományos határait, amelyek megsértését még a kommunista kormányok regionalizálása sem merte felvállalni. A Mečiar-féle szlovák kormány 1996-ban politikai motívumoktól vezettetve - végrehajtott egy területi-közigazgatási reformot, ami olyannyira nem bizonyult időtállónak, hogy négy év múlva, 2000-ben újabb gyökeres átszervezést kellett végrehajtani.

A fent felsorolt példák nagyon különbözö jellegüek, nem összehasonlíthatóak, némelyik közülük egy napon nem is lenne talán emlithetö. Egy csokorba való gyưjtésük inkább egyfajta figyelemfelhívást szolgál. Tény, hogy demokratizálás és 
decentralizálás között van összefüggés. Egy demokratikus állam természetes létformája a decentralizáció, a helyi önkormányzatok nagyfokú autonómiája. Egy demokratikus államban a decentralizáció előbb vagy utóbb utat tör magának, tehát a demokráciából fakad a decentralizáció. De érvényes-e az összefüggés megfordítva is, azaz önmagából a decentralizációból fakad-e demokrácia, egy nem demokratikus, vagy csak „kvázi-demokratikus” államban a decentralizáció szükségképpen több demokráciához vezet-e? A régebbi és legújabb történelmi tapasztalat erre a kérdésre nem ad egyértelmüen igenlö választ. Több országban határozott jelei vannak annak, hogy a demokratikus átmenetben az elsietett decentralizáció az átalakulást nehezítheti, fékezheti ott, ahol ennek a demokráciának nem elég mélyek a gyökerei és a demokratikus meggyőződésú rendszerváltó elitnek térben nem elég széles a társadalmi bázisa. Úgy gondoljuk, hogy Magyarországon ez a veszély már nem fenyeget, a decentralizáció a demokráciát nem veszélyezteti. De azt is gondoljuk - és a megyei közgyúlések listás direkt választásának, ,pártosodásának” tapasztalatai ez irányba mutatnak -, hogy egy közigazgatási funkciójú és reprezentativ testületet is feltételezö regionális terület-átszervezés a magyar demokratizálás folyamatához - mai viszonyaink között - nem is járulna hozzá jelentősen. Sőt, egyfelől az országos, eldurvult politikai viszonyok leképezése, másfelöl a valós, fejlesztési, szabályozási döntési kompetenciák erős behatároltsága együtt elkerülhetelenül a személyi és pozícionális jellegü kicsinyes belharcok dominanciájához vezetne, ezzel hozzájárulva a politikai intézményrendszer tekintélyének hanyatlásához.

\section{Regionalizáció és a decentralizált finanszírozás hatékonysága}

E kérdéskörben két problémát kell szemügyre venni:

- Milyen megtakarítással járhat a megfeleló nagyságrendü régiók kialakítása;

- Ennél lényegesen fontosabb kérdés, hogy mi a makrogazdasági, pénzügyi hatása bizonyos feladatok regionális hatáskörbe, kompetenciába adásának.

Az első kérdésre adandó válasz viszonylag egyszerú. A középszintü területi egységek megnagyobbítása természetesen jár az államháztartásra nézve bizonyos megtakarítással, mivel kevesebb helyen kisebb létszámú köztisztviselőt kell alkalmazni és az ahhoz kapcsolódó kiszolgáló személyzet, valamint a fenntartandó épületállomány és infrastruktúra is kisebb. Nyilvánvaló azonban, hogy pl. a régiók nagyságrendjének kétszeresre növelése nem jelenti a költségek felének megtakarítását, hiszen egy-egy régió kétszeresre növekedett népessége ott nyilvánvalóan több feladat ellátását igényli. Az államháztartás megtakarítása továbbá nem azonos az össztársadalmi megtakarítással, ha a lakosságnak, valamint az üzleti élet és a helyi önkormányzatok képviselöi egy jelentős hányadának ezután többet kell utaznia, több időt kell arra fordítania, hogy a közigazgatás szolgáltatásait 
igénybe vehesse, ügyeit intézze. Ez esetben az állam a költségek egy részét csupán átterhelte az üzleti és a magánszférára. De, ha a távlati költségmegtakaritás jelentős is, az első évek akkor is jelentős többletkiadással járnak az új épületek és infrastruktúra megteremtése, a közigazgatási létszám egy részének átköltoöztetése, másik részének végkielégítési igénye következtében. Ezért ilyen átszervezésbe csak a tartós, hosszú távú megoldás reményében szabad belefogni. Végül az átszervezés nyilvánvalóan nem megtakarítással, hanem többletkiadással jár, ha az új regionális szint nem a régi középszint helyett, hanem amellett új, többletszintként jön létre, vagy, ha a régiók „megnagyobbodása” szükségessé teszi egy új, kisebb közbenső területi szint közbeiktatását (mint a jelen reform során Lengyelországban a járásokét).

Bonyolultabb a második kérdés, az egyes feladatok, hatáskörök középszintre „leadásának" gazdasági, hatékonysági következményei:

Kétségtelenül több érv szól amellett, hogy a döntéseknek a döntés hatásterületéhez közelebb vitele számos elönnyel jár: a döntéshozók sokkal jobban ismerik a helyi viszonyokat, a lokális erőforrások feltárása és hasznosítása könnyebb, a különböző ágazatokba tartozó helyi gazdasági szervezetek érdekei és együttmüködése jobban szervezhetö, érdekeik jobban összehangolhatók. A lakosság és a vállalkozók adófizetési, hozzájárulási hajlandósága, általában aktivitása nő, ha tudja, hogy e források helyben maradnak, a felhasználásba közvetlenebbül beleszólhat.

A döntés lejjebb vitele ugyanakkor veszélyekkel is jár: a döntéshozók nem ismerik döntéseik hatását tágabb környezetükre, a különbözỏ térségekben hozott de egymásra hatást gyakorló - döntések koordinálása, összehangolása nehezebbé válik. Egy kisebb közösségben nehezebb minden döntést a megfelelỏ speciális szakmai ismerettel megalapozni, mivel a rendelkezésre álló speciális szakértelem szükségszerüen korlátozottabb; kisebb közösségben a döntéshozók személyes érintettsége vagy befolyásolhatósága és ez által az összefonódás valószinüsége is szükségszerủen nagyobb.

Az előnyök és a veszélyek puszta felsorolásán túl a mérlegelést csak konkrét esetek, példák tapasztalatainak értékelése segítheti. A kelet-közép-európai viszonyokra alkalmazható konkrét példákat találni viszont nehéz, mivel a ,reálisan létezỏ szocializmus" szélsőségesen centralizált, ágazati szervezeti vonalakon irányított rendszer volt, így a központosított rendszer hátrányaira, hibáira bőségesen vannak példáink, ezzel összevethetổ térben decentralizált döntési rendszerekre viszont alig.

Néhány tapasztalat mégis rendelkezésre áll. 1958-59-ben Hruscsov meg akarta törni a vele szembenálló szovjet ágazati szakbürokrácia hatalmát, és ennek érdekében létrehozta a területi „Népgazdasági Tanácsok (Szovnarhoz-ok)” rendszerét, amelyeknek át kellett venniük a szövetségi és köztársasági ágazati 
minisztériumoktól a termelési, valamint fejlesztési tervezés és döntéshozatal feladatát. A rendszer néhány éven belül - Hruscsovval együtt - megbukott. Számunkra tanulságosabb azonban, hogy a kisebb államok közül az akkori leghüségesebb tanitvány, Bulgária is rövidesen átvette a szovjet példát, és régióiban bevezette a Népgazdasági Tanácsok, a decentralizált tervezés és termelésirányítás rendszerét. Az eredmény katasztrofális volt (Mihailović 1972). A régiókban egyremásra indultak a párhuzamos fejlesztések, ráadásul azok szakmai, múszakigazdasági, külpiaci megalapozottsága - a megfelelö helyi intézményrendszer és háttér hiányában -, ha ez egyáltalán lehetséges, még a korábbiaknál is alacsonyabb szintủ volt. Kiderült, hogy nem a tervezés ágazati rendszerével, hanem a központi direktív tervgazdasággal van az alapvetỏ baj, amin a decentralizálás, a területi elvü átszervezés semmit nem segít, sőt, ha lehet, még ront is az ágazati rendszerrel szemben.

Jogos az ellenvetés, hogy a mai piacgazdasági rendszerben egészen más jellegủ feladatai vannak a regionális kormányzatoknak, mint a központosított direktív tervgazdaságban, és azt egészen más politikai-gazdasági környezetben hozzák meg. A koordinálatlan és párhuzamos helyi döntésủ fejlesztések veszélye ennek ellenére itt is fennáll, és hogy a veszély reális, azt a kilencvenes évek első felének számtalan magyarországi, elaprózott párhuzamos tanterem, tornaterem, vízmú, szennyviztisztítómü és szemétlerakó fejlesztése, párhuzamos kórházi diagnosztikai és egyéb orvosi müszer-beszerzése is igazolja.

A decentralizált finanszírozás térnyerésének legnagyobb akadálya azonban nem is ez: A XX. század második felének tapasztalata az volt, hogy a tudományos kutatás és müszaki fejlesztés hihetetlenül megnövekedett költségigénye, a kiépített társadalmi, jóléti rendszerek, no meg a világpolitikai, világgazdasági szerepvállalás olyan mértékben megnövelték sok országban a központi kormányzatok forrásigényét, hogy még a decentralizáció áldásos hatásairól legjobban meggyőződött országokban is a valóságban ennek éppen az ellenkezője játszódott le. Legpregnánsabb példája ennek a föderalizmus szülöhazája, az Amerikai Egyesült Államok, de számos más országból is lehetne hasonló adatokat idézni (1. táblázat).

1983 után, a „Reaganomics” hatására a szövetségi centralizáció kis mértékben enyhült, de az arányok lényegesen nem változtak.

Tanulságok azonban hozzánk közelebb is vannak. A rendszerváltozás küszöbén, vagy közvetlenül azt követően számos közép-európai ország széles körü hatásköröket és lehetöleg azokhoz rendelt eröforrásokat biztosított a helyi önkormányzatoknak. Az évtized folyamán azonban a gazdasági válság, az államháztartásba bevonható források beszükülése, valamint a központi állam megnövekedett feladatai a legtöbb kormányzatot a forrás-decentralizáció szükítésére kényszerítette. Minden bizonnyal voltak politikai, hatalmi motivációtól vezetett centralizációs intézkedések is, de a 
tendencia általános jellege arra mutat, hogy a folyamatban objektív tényezők is jelentős szerepet játszottak.

\section{TÁBLÁZAT}

Költségvetési kiadások szintek szerinti megoszlása az USA-ban, 1929-83

(The Budgetary Expenditures by Different Regional Levels in the USA between 1929-83)

\begin{tabular}{ccccc}
\hline Év & $\begin{array}{c}\text { Költségvetési } \\
\text { kiadások } \\
\text { összesen } \%\end{array}$ & $\begin{array}{c}\text { Szövetségi szint } \\
\%\end{array}$ & $\begin{array}{c}\text { Szövetségi } \\
\text { államok } \\
\%\end{array}$ & $\begin{array}{c}\text { Helyi } \\
\text { onkormányzatok } \\
\%\end{array}$ \\
\hline 1929 & 100 & 25,6 & 20,8 & 53,6 \\
1939 & 100 & 50,9 & 21,2 & 28,0 \\
1983 & 100 & 70,2 & 17,4 & 12,5 \\
\hline
\end{tabular}

Forrás: Advisory Commission... (1985).

\section{TÁBLÁZAT}

A helyi önkormányzatok kiadásai a GDP százalékában Közép- és Kelet-Európa országaiban

(Expenditures of Local Governments in Percentage of GDP in the Central and Eastern European Countries)

\begin{tabular}{lcc}
\hline Ország & $1988-91$ & $1997-98$ \\
\hline Ausztria & $9,1^{\mathrm{c}}$ & $8,8^{\mathrm{c}}$ \\
Bulgária & $13,3^{\mathrm{b}}$ & $9,8^{\mathrm{f}}$ \\
Észtország & $10,5^{\mathrm{d}}$ & $8,8^{\mathrm{f}}$ \\
Németország & $8,6^{\mathrm{b}}$ & $7,3^{\mathrm{f}}$ \\
Magyarország & $14,7^{\mathrm{b}}$ & $13,3^{\mathrm{f}}$ \\
Litvánia & $10,3^{\mathrm{d}}$ & $8,1^{\mathrm{f}}$ \\
Lengyelország & $14,0^{\mathrm{a}}$ & $10,1^{\mathrm{f}}$ \\
Románia & $3,7^{\mathrm{a}}$ & $4,3^{\mathrm{e}}$ \\
\hline
\end{tabular}

Megjegyzés: a: 1988; b: 1989; c: 1990; d: 1991; e: 1997; f: 1998

Forrás: Government Finance Yearbook (1999) alapján a szerző összeállítása.

A 2. táblázatból látható, hogy a kilencvenes évtized folyamán - Románia kivételével - valamennyi országban csökkent a helyi önkormányzatok kiadásainak részesedése a GDP-ből. A kivételt képező Romániában azonban ez a megnövekedett részesedés is oly csekély, hogy nem éri el a többi ország átlagának felét sem. Magyarország esetében ez a két időpont nem is mutatja teljesen a visszaesés valódi nagyságrendjét, mert 1989-töl 1993-ig az önkormányzati kiadások részesedése a GDP-böl még növekedett. Az önkormányzatok részesedése a GDP- 
böl 1993-ban 16,9 százalék volt, 1999-ben pedig 11,9 százalék. Számos jel mutat arra, hogy ez a tendencia a következö években még folytatódik. Ennek tükrében különösen óvakodni kell olyan illúzióktól, hogy a regionalizáció automatikusan az eszközök, a források és a valós döntési kompetenciák decentralizációját is jelenti.

De, ha feltételeznénk, hogy a források rendelkezésre fognak állni, akkor merül fel a kérdés, melyek azok a kompetenciák és funkciók, amelyek a középsö szintnek adandók, ahol a szubszidiaritás elvének megfelelöen ez az a szint, amelynél a döntést lejjebb már nem célszerü vinni, ahol tehát a döntés tényezöiröl legnagyobb az áttekintés és az érintettek érdekeltsége a legközvetlenebbül ezen a szinten jelentkezik?

Aki valaha megyei vagy regionális fejlesztési tervet készített, az jól ismeri azt a dilemmát, hogy mi az a „hozzáadott érték”, amit ezek a tervek az országos átfogó és ágazati koncepciókhoz, illetve a falvak, városok, kistérségek terveihez hozzáadhatnak. Mindig fennáll a veszély, hogy e koncepciók csupán megismétlik, illetve összesítik a különböző országos és ágazati koncepciókban már megfogalmazott célokat, projekteket, hiszen a nagy infrastrukturális hálózatok tervezése ott történik, amihez a megyék, régiók legfeljebb módosító javaslatokat tehetnek, általában csekély eredménnyel. Ha pedig a megyék, régiók tervezése a nagyobb mélység és részletesség irányában fejlődik, akkor mindjárt felmerül annak veszélye, hogy olyan kérdésekben foglalnak állást, hoznak döntéseket, amelyek a helyi - városi, községi - önkormányzatok vagy kistérségi szervezödések kompetenciájába tartoznak. Az olyan kis országok esetében, mint amilyen a középeurópai országok többsége, köztük Magyarország is, rendkívül keskeny és nehezen azonosítható az a kompetenciasáv, ami az országos és a helyi döntési jogosultságok között fennmarad.

Természetesen mindig fennáll az a lehetőség, hogy e régiók pénz-elosztó, támogatás-elosztó funkciót töltsenek be. Ez lényegében a mai megyei területfejlesztési tanácsok fö funkciója, és ez lenne a regionális tanácsok fö funkciója is. Csakhogy nem mindegy, milyen típusú támogatások kerülnek elosztásra. A közép- és délkelet-európai országok közül csak Magyarország rendelkezik területfejlesztési és vidékfejlesztési alapokkal, ezért csak ebböl vonhatunk le némi tapasztalatot. E tapasztalatok szerint az ún. kiegyenlítő területfejlesztési támogatások egésze, a területfejlesztési céltámogatásnak pedig jelentös része a települések alap-infrastruktúra fejlesztéseinek támogatását szolgálja. Önmagában a fejlesztési cél jogosultságához semmiféle kétség nem férhet, az elosztás módszeréhez annál inkább. Éppen ez az elosztási, osztogatási gyakorlat volt az, ami az elmúlt rendszerben a városokat és a községeket a megyékkel szembefordította. A rendszerváltozás után éppen emiatt vonták meg a megyéktől a pénzelosztás illetve újraelosztás kompetenciáját, és - a megfelelö feltételek megléte esetén automatikus jogosultsággal - a parlament hatáskörébe 
utalták a céltámogatások odaítélését. Az önkormányzati források, ezen belül a tulajdonképpeni céltámogatások beszükülése nyitott teret annak, hogy az alapinfrastruktúra egyre nagyobb hányadát ismét csak bizottságok által osztogatott pénzekből lehet megvalósítani. Pedig e beruházások valójában a szó legjobb értelmében vett város- és településfejlesztés körébe tartoznak, és nem is tekinthetők területfejlesztésnek, nincs tehát semmi ok arra, hogy róluk egy, a tẹlepülésen kívüli bizottság vagy testület döntsön.

A támogatások másik lehetséges szférája a kis- és közepes vállalatok támogatása. Erről már célszerú településnél nagyobb léptékben dönteni, és ez a döntés valóban egyedi mérlegelést igényel, nem lehet automatikusan odaítélni. A probléma itt azonban az, hogy köztisztviselőkből és választott politikusokból álló testületek nem igazán alkalmasak ilyen típusú támogatások odaítélésére, különösen akkor, ha a választható projektek körében alap-infrastruktúra fejlesztések és gazdasági vállalkozások egyaránt vannak. Politikusok, önkormányzati tisztségviselök érdekeltségébe elsősorban kommunális, infrastrukturális fejlesztések tartoznak, ezek megvalósítása esetén választják őket újjá, ezért nagy valószinüséggel ezeket preferálják. Ráadásul egy vállalkozást támogatni mindig kockázatos, az csődbe mehet, ráfizetéses lehet, míg egy infrastrukturális fejlesztés sohasem válik ilyen nyilvánvaló kuđarccá. A kockázatkerülö bürokrácia már csak ezért is az utóbbit részesíti előnyben. Ez is az oka annak, hogy a magyar területfejlesztési alapok eddigi gyakorlatában olyan túlnyomó arányban támogattak kommunális és alapinfrastruktúra fejlesztéseket és oly kevés jutott a gazdasági vállalkozások támogatására. Ez utóbbi támogatásokat, kedvezményeket inkább a bankszerü elbírálás körébe kellene utalni. Persze a közép- és kelet-európai bankoknak, bankrendszereknek is megvannak a maguk problémái, de mégis jobban remélhetö, hogy előbb-utóbb „felnőnek” ehhez a feladathoz. Arra az ellenvetésre pedig, hogy az EU támogatásokat is bürokratikus, tisztviselőkből álló bizottságok osztják el, azt lehet válaszolni, hogy ez igaz, de attól még nem biztos, hogy az a helyes megoldás.

\section{Regionalizáció és a mai magyar viszonyok}

A regionalizációról szóló általánosabb érvényủ fejtegetések után nézzük most, milyen következtetések vonhatók le ezekbỏl a konkrét, mai magyar viszonyokra?

A regionalizáció Közép- és Délkelet-Európában sehol sem könnyủ feladat. Sok országban a nemzet egységét féltik tőle, máshol a korábbi gyakori átszervezések miatt van elegük belöle. Magyarországon a fenti két ellenérv közül egyik sem érvényes, a problémák mégsem csekélyek:

Az ellenérzés részben abból fakad, hogy a megye magyar „találmány”, méghozzá közel ezer éves, a régió pedig nem az. Igaz, a megyék sem mindig a haladás, a demokrácia és az európaiság fellegvárai voltak, de mégis, hosszú fennállásuk alatt a magyar alkotmányosság és függetlenség fontos letéteményeseivé váltak. Ezzel 
szemben minden eddigi regionalizálási kísérlet kívülröl jött, és a tradicionális magyar közigazgatási struktúrák széttörésének szándékával kívánták bevezetni: kezdve Kollonich Lipót érsek átszervezési tervétöl, II. József kerületein és Bach Sándor körzetein át Rákosi Mátyás szovjet típusú regionalizálási terveiig. A megyék azonban, legalábbis alapvetö területi kereteik tekintetében, túlélték mindezen átszervezési kísérleteket, miközben tartalmukat és müködésüket illetően minden rendszer a maga képére formálta őket. Így történt ez a szocializmus évtizedei alatt is, amikor a megye a párt- és állami hatalom lényeges centruma lett, annak minden velejárójával.

Nem véletlen tehát, hogy a rendszerváltó elit nem rokonszenvezett a megyékkel. $\mathrm{Az}$ új önkormányzati törvény azok hatáskörét - hasonlóan a többi közép-európai országhoz - radikálisan megnyirbálta. Egy érzékletes képet idézve: az MDF levágta a megyei tanácsok karjait, amikor ágazati és szakmai kompetenciáinak jelentős hányadát a dekoncentrált szervekhez csoportosította át, az SZDSZ levágta a megyei tanács lábait, amikor megszüntette hierarchikus viszonyát a helyi tanácsokkal, a FIDESZ pedig levágta a fejét, amikor valamennyi megyeszékhelyet és nagyvárost, kivéve azokat a megyei hatáskörből, megyei jogú várossá nyilváníttatta. De lehetséges, hogy ez már nem volt más, mint egy boncolási múvelet, mivel a páciens már ezt megelőzően megfulladt, amikor 1989-ben a Németh-kormány adózási és tanácsi finanszírozási reformja mindenfajta saját átengedett és helyi adó bevételt megtagadott a megyei tanácsoktól. 1994-ben, az új választások után, a megyei önkormányzatok feladat- és hatáskörét némileg kibővítették, de az új feladatok - az MSZP megyepárti és az SZDSZ megyeellenes nézeteinek kompromisszuma eredményeként - inkább szimbolikus, mint tényleges hatáskörnövekedést jelentettek.

Az elmúlt évtized során mindkét mai vezetö párt - az MSZP és a FIDESZ - a regionalizálást illető nézeteiben több hátraarcot mutatott be:

Bár a megyéket még a Németh-kormány zárta ki a saját bevételek szerzéséből, az MSZP az évtized túlnyomó részében alapvetően megyepárti volt. Közrejátszott ebben az, hogy az első, 1990 őszén létrejött megyegyülések többsége MSZP-s vagy MSZP szimpatizáns elnököt választott. 1994-ben, hatalomra kerülése után az MSZP-kormány nyomban megszüntette az Antall-kormány által létrehozott, több megyéböl alkotott régiókra kiterjedő hatáskörü köztársasági megbízottak intézményét, visszahelyezve az állami dekoncentrált közigazgatás intézményeit a megyei keretekbe. A megyék melletti elkötelezettséget tovább erősítette az 1994. évi önkormányzati választásokon az MSZP újabb megyei térnyerése.

$\mathrm{Az}$ 1998. évi önkormányzati választásokon azonban a helyzet megváltozott: a megyék élére az esetek többségében FIDESZ-es vezetés került. A kormányzat pedig megkezdte a régiók státuszának megerősítését, ott az állami jelenlét fokozását. Az MSZP-nek két számára kedvezőtlen fejleménnyel is szembe kellett 
néznie: az egyik a megyei pozíciók már bekövetkezett elveszítése, a másik a kormányerök által dominált pénzosztó régiók létrejöttének veszélye. Ilyen körülmények között történt meg a régiókkal kapcsolatos MSZP politika gyökeres megváltozása: az erős, önkormányzati régiók koncepciójának támogatása. A megyék feladásával már nem veszíthettek sokat, és megvolt a valószinüsége, hogy az újonnan létrehozandó önkormányzati régiókban a következö - vagy egy idöközi - választáson többséget szerezhetnek. Mindenesetre tény az, hogy a fö kormánypártot váratlanul érte a fö ellenzéki párt regionalizálási terveihez nyújtott hirtelen támogatása.

A FIDESZ a kilencvenes évek elején a megyei rendszer egyik fó ellenzöje volt. $\mathrm{Az}$ ifjonti, mindent megváltoztatni kívánó hév mellett ebben minden bizonnyal közrejátszott az is, hogy a FIDESZ az első szabad önkormányzati választásokon a nagyvárosokban szerzett jelentós pozíciókat, továbbá, hogy ezen nagyvárosok polgármesterei - esetleg korábbi tapasztalataik alapján - nem a leghízelgőbb véleményt alakították ki a megyék tevékenységéről. Olyan területi egységek kialakításáról gondolkoztak, amelyek centrumában a nagyvárosok és azok területszervezô szerepe állna. Ha a megyékkel szembeni ellenséges magatartás a későbbiekben valamivel enyhült is, ez a politikai alapállás az 1998. évi választásokig alapvetően nem változott. Csak, amikor 1998-ban kormányra került a FIDESZ, akkor kezdte felmérni egy ilyen területi átszervezés várható nehézségeit. A meglévő struktúrák megőrzésének politikai vonzóerejét növelte az 1998. őszi önkormányzati választás eredménye, amikor a megyék nagyobb hányadában kormánypárti többségü közgyülés és vezetés jött létre. Mindamellett a kormány folytatta - nem utolsósorban az Európai Bizottság ösztönzésére - a tervezési régiók kialakítását, a megalakításokat érintő szabályokat egyértelmübbé és kötelező érvényüvé tette, egyidejüleg gondoskodott arról, hogy irányító szervezeteikben biztos kormányzati többség alakuljon ki. A megyei önkormányzati rendszer régiókkal való felváltásának terve időközben az egyre távolabbi és ködösebb jövőbe tolódott ki, és a vezető kormánypártot e halasztó szándékában nyilvánvalóan megerösítette az MSZP hirtelen jött regionalizáló buzgalma.

A két vezető párt radikális koncepcionális irányváltásai a regionalizáció kérdésében talán nem túl rokonszenvesek, de mindenesetre megerösítik azt a legtöbb országban szerzett - hasonló tapasztalatot, hogy a regionalizáció nem elvek, sokkal inkább napi politikai taktika és eröviszonyok kérdése.

Ezt is figyelembe véve kockáztatható meg az a megállapítás, hogy egy, a rövid, vagy akár középtávon végrehajtott, erőltetett közigazgatási(!) regionalizálás nem tenne jó szolgálatot sem a kormánypártoknak, sem az ellenzéknek, de ami a fö, a magyar stratégiai regionalizálás ügyének sem.

A kormánypártokat illetöen a helyzet világos: ha a jelenlegi lengyel és cseh kormányok a következö választáson meg fognak bukni - ami eléggé valószínü - 
akkor abban jelentős tényezỏ lesz az erőltetett, elsietett és átgondolatlan közigazgatási átszervezés, regionalizáció is:

Lengyelországban annak a 33 vajdasági székhely-nagyvárosnak a sérelmei, amelyek elveszítették vajdasági székhely-funkciójukat (összesen mintegy 5 millió lakossal!); az új járási szint létrehozása, amit a helyi önkormányzatok, kisvárosok, községek sérelmeznek, de föleg az a kaotikus helyzet, ahol sem az egyes szintek, sem azon belül az állami és önkormányzati szervezetek hatáskörei nem tisztázódtak, és a választási ígéretekhez képest a decentralizáltan elkölthető források sem növekedtek.

Csehországban pedig olyan régiók létrehozása, amelyekkel a lakosság nem tudja azonosítani magát, sokan nem látják igazán értelmét, és ismét föleg az új régiók politikai szerepköre körüli áldatlan viták és mindmáig ködös, tisztázatlan elgondolások. A FIDESZ valószínúleg belátta már, hogy ez az átalakítás számára semmi politikai hasznot nem hozna és nagy valószínủséggel a lengyel és cseh kormánypártok sorsára juttatná.

Ez az egy, utolsóként említett következmény nem lenne ellenére az ellenzéknek, és ebben az értelemben ők akár érdekeltek is lehetnének egy gyors regionalizációban. A dolog érdemét tekintve azonban ök sem érdekeltek benne. A regionalizáció a politikai küzdelmet önmagában nem dönti el, a választási győzelemnek vagy vereségnek az csupán egy tényezője lehet. Így annak gyors megvalósulása győzelmük esetén egy megoldatian vagy félig megoldott problématömeggel szembesítené óket, ha pedig továbbra is ellenzékben maradnak, akkor olyan régiókkal kell együtt élniük, amelyeket a kormányzat valószínủleg nem az ő szájuk íze szerint alakítana ki.

Amint azonban már említésre került, a gyors átszervezés leghátrányosabb lenne magának a távlati, stratégiai regionalizációnak a szempontjából:

Kedvezötlen lenne, mert az adott kialakult struktúrák közepette, amikor a helyi és országos szint között oly kevés igazi eldöntenivaló van, a regionális szint létrehozása csak a szervezetek számát növelné anélkül, hogy érdemben hozzá tudna járulni a döntési rendszer fejlesztéséhez. Jellemző momentum, hogy a parlament és a kormányzat elöször létrehozta a Regionális Fejlesztési Tanácsokat, és utána kezdtek el gondolkodni azon, hogy azoknak ténylegesen - és nem a tartalom nélkül megfogalmazott, de jól hangzó törvénystrigulák formájában - mit is kellene csinálni, milyen feladatokat lehet adni.

Kedvezőtlen lenne, mert az általános forráscentralizáció tendenciájának közepette nem teremtődne meg a régiók gazdasági-pénzügyi háttere, és ezen az Európai Uniótól származó támogatások sem változtatnának lényegesen. Vegyünk csak egy példát: a társult országok évi 1 milliárd eurós ISPA támogatási keretéből Magyarország 7-10 százalékkal, átlagban tehát 85 millió euróval részesül. Az eddigi európai tapasztalatok szerint ennek mintegy 80 százaléka országos, központi projektekre 
kerül felhasználásra és mintegy 20 százalék felett döntenek decentralizáltan: ez 17 millió euró. A 7 magyar régió között elosztva, egy régióra jut 2,42 millió euró. Tekintettel arra, hogy az EU új szabályzata szerint az ISPA projekteknek minimálisan el kell érniük az 5 millió euró nagyságrendet, ez azt jelenti, hogy egy régióra évente maximálisan „f́el" projekt jut, azaz egy-egy regionális tanács kétévente vitathat meg és dönthet (dönthet?) egy-egy ISPA projekt felöl. Kérdés, hogy ehhez a kétévenkénti döntéshez milyen döntési és menedzsment apparátust kell létrehozni?

Kedvezötlenek az induló feltételek, hiszen a Regionális Fejlesztési Tanácsokban ma meghatározó súlyt képviselnek a központi szervek illetve a kormányzó pártok képviselöi. Ha ebböl a kiinduló helyzetböl kell egy autonómabb, önkormányzati régió felé elindulni, úgy a megteendő út bizony elég hosszú lesz és ez a kiinduló pont a régió helyét, funkcióját és jövőjét hosszabb távra beárnyékolja.

Végül kedvezötlen a kiinduló helyzet, mert a régiók létrehozásához és a régiók tervezéséhez elengedhetetlen, hogy az országos szervek is régiókban gondolkodjanak, és legyen olyan átfogó országos tervezés és stratégia, amely a régiók számára is megfogható, irányadó kiindulópontot és követelményeket tartalmaz. Régiókban gondolkodó országos tervezés és stratégia nélkül nincs megvalósitható regionális szintü tervezés és stratégia. Sajnos ilyen fajta, régiókban való gazdaságpolitikai gondolkodás sohasem volt Magyarországon, és jelenleg sincs. Paradox módon erre a legjobb bizonyítékot éppen a kormányzatnak egy, a területiség irányában tett gesztusa szolgáltatja: a 2000. évre szóló költségvetés 58. §-a elöírja, hogy 6 minisztérium 16 fejezeti kezelésü elöirányzatának - a teljes összeg mintegy 40 milliárd forint - 20 százalékát a legalacsonyabb egy före jutó GDP-vel rendelkezö 5 megyében (Borsod-AbaújZemplénben, Szabolcs-Szatmár-Beregben, Nógrádban, Somogyban és Békésben) kell felhasználni. A fejezeti kezelésủ elöirányzatok között olyanok vannak, mint mezögazdasági beruházások, erdőtelepítés, öntözés, turisztika, útfenntartás, vízgazdálkodás, műszaki fejlesztés, nemzeti kulturális örökség, valamint szociális válságkezelés. Sem a kormányban, sem a parlamentben nem merült fel, hogy vajon ennek az öt megyének tényleg egyforma országos súlya van az erdötelepítés, az öntözés, a turisztika és a nemzeti kulturális örökség szempontjából? Senki nem készitett elözetes számitást, mi az ésszerủ és differenciált részesedése, súlya és igénye ennek az öt megyének ezekben a nagyon különböző földrajzi elhelyezkedésü és különböző telepitési igényekkel rendelkezö ágazatokban? A müszaki fejlesztési alapokból például aligha lehet 20 százalékot itt hatékonyan felhasználni, hiszen a meglévő kutató- és fejlesztỏ bázisból ez az öt megye maximum 5-6 százalékkal részesedik. Csak remélni lehet, hogy ez az elöirányzat nem a törvény betủje, hanem szándéka szerint fog teljesülni. Mindenesetre, mindaddig, amíg az országos gazdaságpolitika ilyen keretfeltételeket ad meg, illetve ezeknél megalapozottabbakat nem ad meg, addig a regionális tervezés csak arra lesz jó, 
hogy azok előirányzatainak összesítése után a központi és ágazati szervek bebizonyíthassák - és joggal - e tervek felhasználásra való teljes alkalmatlanságát.

$\mathrm{Az}$ elmondottak korántsem jelentik azt, hogy ne kellene az Európai Unió kívánalmait teljesíteni a programozási régiók kialakítása tekintetében. Valamennyi társult ország ezt teszi. De a tíz társult ország közül egyedül Lengyelország alakított eddig ki a NUTS 2 szintnek megfelelö önkormányzati jellegủ területi-közigazgatási egységeket (Csehországban és Szlovákiában a reform keretében kialakítandó területi önkormányzati egységek sem fognak annak megfelelni). Minden más országban e programozási régiók kisebb közigazgatási egységek csoportjaiként alakultak meg, ahol csak a tervezési, programozási, az EU támogatások odaítélésével, ellenőrzésével kapcsolatos funkciók a közösek. Éppen ezért a legtöbb ország e csoportosítás kialakításánál bizonyos taktikai meggondolásokat is figyelembe vett a támogatás szempontjából elönyös lehatárolás érdekében. Ez a magatartás egészen természetes: ha egyszer az EU csatlakozás követelményeinek teljesítése, és nem utolsósorban a strukturális alapok fogadási feltételeinek megteremtése érdekében hozzuk létre e régiókat, badarság lenne, ha a strukturális alapok szabályait e regionalizálás során ne vennénk figyelembe.

Magukat a megyéket is, amikor régiókhoz való tartozásukat kivánták meghatározni, természetesen - és teljesen érthetően - bizonyos taktikai szempontok is vezérelték. A baj csupán az, hogy nem ismerték kellő alapossággal a strukturális alapok szabályozását és annak várható változásait, ezért egyes esetekben saját valódi távlati érdekeiknek nem teljesen megfelelő csoportosulásokhoz csatlakoztak. Lássunk néhány példát:

A Dunántúlt hagyományosan két régióra Észak- és Dél-Dunántúlra osztották. A ma kialakított regionalizálás három régióból áll: Nyugat-, Közép- és DélDunántúlból. Az ,újítás” nem utolsósorban annak eredménye, hogy a három nyugati határ menti megye az Európai Unió PHARE CBC határ menti együttmủködési programja keretében bizonyos támogatáshoz jut, és e megyék Györ-Moson-Sopron, Vas és Zala - attól féltek, hogy a hagyományos régió-képzés esetében osztozniuk kell e támogatáson a többi dunántúli megyével. Pedig az aggodalom teljesen alaptalan, a határ menti együttmủködési támogatást az EU-ban sem a NUTS 2 szintủ nagyrégiók, hanem az annál kisebb NUTS 3 és NUTS 4 egységek, azaz nálunk a megyék és kistérségek kapnák. A ,veszély” a DélDunántúlt elhagyó Zala megyére éppen a jelenlegi regionális struktúrában leselkedik. A gyorsan fejlődő és a megyék között élre került Győr-Moson-Sopron és Vas megyék rövidesen kikerülhetnek a támogatási körből - ami a bővítés utáni új EU fejlettségi átlag 75 százaléka alatti kört fogja át -, és az egy régióba tartozás révén „magukkal ránthatják" a kevésbé fejlett Zala megyét is. De maga GyőrMoson-Sopron és Vas megye is nagyobb biztonsággal maradhatna benn a támogatott körben az öt megyét átfogó észak-dunántúli régió keretében. 
Szabolcs-Szatmár-Bereg megye időközben elhunyt közgyülési elnöke mindvégig azért küzdött, hogy megyéje önállóan képezzen egy régiót, ne olvadjon bele egy nagyobb egységbe. Ennek fö oka nyilvánvalóan a területfejlesztési támogatások miatti aggodalom volt. Az elmúlt évtizedben e támogatások messze legnagyobb hányadát ez a megye kapta. Attól tartottak, hogy egy nagyobb régióban ez a támogatás kevésbé koncentrálódna Szabolcs-SzatmárBereg megyére. A regionalizáció után a megye részesedése az EU támogatásaiból valóban nem lesz ilyen nagy, de ennek semmi köze a regionalizáláshoz. Az EU szempontjából ugyanis Magyarország túlnyomó része elmaradottnak minősül, a támogatások tehát több térség között fognak megoszlani. Az EU azonban - az elmaradottságból fakadó igény mellett - egy másik faktort is mérlegel, az. ún. beruházás-abszorpciós képességet, melynek felső határát az illető ország illetve régió GDP-jének 4 százalékában szabott meg. Ez a GDP és az ebből fakadó „,abszorpciós képesség” Szabolcs-Szatmár-Bereg megyében elég korlátozott, ami a támogatásoknak itt egyébként is szükebb határt szabna. Lehet azonban, hogy a megye jobban jár, ha valamivel fejlettebb, de még támogatásra jogosult más megyékkel egy régióba társul: ez esetben a támogatást a régió magasabb abszorpciós kapacitása szabja meg, amiből a megye - ügyes politikával - magának nagyobb szeletet ,hasíthat ki."

Végül e taktikai szempontokból a legkritikusabb kérdés a Budapestet és Pest megyét magában foglaló Központi Régió problémája. Budapest egy före jutó GDPje az EU jelenlegi átlagának 92 százaléka, meghaladja a 75 százalékot, önmagában tehát semmiképpen nem lenne jogosult az elmaradottnak számító régióknak járó (az ún. 1. Cél szerinti) támogatásra. Még inkább így lesz ez a bövités után, ami az EU átlagot 13-15 százalékkal lejjebb viszi, Budapest GDP-je tehát a bővités utáni EU átlag 107 százaléka lenne. Pest megye GDP-je csak az EU átlag 34 százaléka, de Budapesttel egyesítve a régió átlaga így is a jelenlegi EU átlag 72 százaléka, a bővítés utáninak 84 százaléka. Az utóbbi adat alapján tehát a régió már ma sem lenne jogosult a támogatásra. A közös régióban tehát Budapest fejlettsége a nála jóval kevésbé fejlett Pest megyét is támogatásra jogosulatlanná teszi, saját 2 milliós lakosságán kívül további közel 1 millió fövel csökkenti Magyarországon a strukturális támogatásokra jogosult lakosság számát. Kétfajta lehetőség van ennek elkerülésére. Az egyik a föváros önálló NUTS 2 régióvá nyilvánitása. Ezt a módszert követte a társult országok közül Csehország, Szlovákia, Románia és Bulgária (a balti országok és Szlovénia egészben alkotnak egy-egy régiót). A másik módszer a föváros régiójának oly mértékủ kiszélesítése, hogy a csatlakozó területek ellensúlyozzák Budapestet és „lehúzzák” a régió átlagos GDP-jét. Ezt az utat követte Lengyelország. Valamennyi ország közül a magyar „módszer” - a városon kívülre kiterjeszteni a régiót, de nem annyira, hogy a csatlakozó területek 
alacsonyabb jövedelemszintje ellensúlyozza a föváros kiemelkedő értékét - a legkevésbé szerencsés.

$\mathrm{Az}$ elsőként említett módszer, Budapest önálló régióvá tétele, természetesen nyitva áll Magyarország előtt is. Pest megye így egyértelmủen támogatásra jogosulttá válna. A második módszer viszont már jóval problematikusabb. Magyarország ugyanis nem Lengyelország: az ország jóval kisebb és ehhez képest a főváros jóval nagyobb. Ahhoz, hogy a központi régió szintjét a jogosultsági szintre, a bővítés utáni átlag 75 százaléka alá „le lehessen vinni” további 8-900 ezer lakosú területet, minimum további három, de inkább négy megyét kellene hozzá csatolni. E módszer még azzal is igazolható, hogy e megyékre vagy azok egy részére (Fejér, Komárom-Esztergom, Nógrád, Jász-Nagykun-Szolnok, esetleg Heves) a főváros vonzásterülete ténylegesen kiterjed. Mégis itt van az a pont, ahol a taktikai szempontok már komoly stratégiai érdeket sértenek. Ha ugyanis egy négymilliós, az ország lakosságának 40 százalékát magában foglaló Központi Körzetet alakítunk ki - akár csak programozási-fejlesztési régióként is -, akkor minden más régió eleve periférikus létezésre van ítélve, és esélye sincs annak, hogy vidéki nagyvárosaink valamiféle ellenpólus szerepet játszhassanak.

A taktikai szempontokat ugyan el lehet, és néha el is célszerü választani a stratégiaiaktól, de bizonyos határokon túl ez már nem lehetséges. Ezért kellene a regionalizációt alaposan elökésziteni és arról nem hiedelmek és érzelmek, hanem tények, előnyök és hátrányok mérlegelése alapján széles körü vitát folytatni.

\section{Jegyzet}

${ }^{1}$ Valószínüleg erre reagálva jelentette ki John Bruton, akkori ír miniszterelnök 1996-ban - félig viccesen, félig komolyan - egy konferencián, ahol e tanulmảny szeröje is jelen volt: „Az egész föderalizmus és regionalizmus a németek revansa, bosszúja Európán. Annak idején, a második világháború után az amerikaiak ráeröltették saját föderatív rendszerüket a németekre, és a németek most bosszúból ugyanezt akarják ráeröltetni egész Európára."

\section{Irodalom}

Advisory Commission on Intergovernmental Relations: Significant Features of Fiscal Federalism. 1984. (1985) Edition, Washington.

Government Finance Yearbook. (1999) International Monetary Fund, Washington.

Kinsky, F. (1995) Föderalismus: ein gesamteuropäisches Modell. Eur'pa-Union Verlag, Bonn.

Mihailović, K. (1972) Regional Development Experiences and Prospects in Eastern Europe. The Hague, Mouton. 


\section{REGIONS AND REGIONALISATION}

\section{IVÁN ILLÉS}

The question of regions and regionalisation appears more and more in the Hungarian press. We established new institutions (e.g. Regional Development Council), the composition of which became the subject of political debate. Building of planning, development, financing and monitoring institutions and professional capacities in regional level is one of the important elements of the requirements of the EU accession. Of course different stakeholders have different opinions about this question and they give voice to it. Today the question of regions and regionalisation is well known.

According to the experiences the image of Central and Eastern European regions and regionalism in Western Europe and the image of Western European regions in Eastern European countries is one-sided and unreal. According to Western European people Central and Eastern European countries are absolute centralised states, where the absence of democracy means total centralisation. However there are idealised conceptions about Western regionalism, democracy in Eastern countries as well. Behind this idealisation can be found some propagandist intentions too. These are models - and demands - to be followed in the institution-building process in Central European countries. The author believes in regionalism, but in a very special one. As a consequence of it counter-arguments of the regionalisation particularly the argument against quick and radical regionalisation are prevailed in the study. In my opinion we, regional researchers know these counter-arguments and it is our duty to answer them before our proposals. 